\title{
Distribution of the major forest tree species in Turkey within spatially interpolated plant heat and hardiness zone maps
}

\author{
Osman Yalçın Yılmaz, Doğanay Tolunay
}

In disciplines such as agriculture, forestry and horticulture, it is customary to make use of various hardiness zone maps intended for the selection of the plant species to be cultivated within specific regions. The most widely used of these maps is the USDA Plant Hardiness Zone (PHZ) map. Recently, the American Horticultural Society also created the Plant Heat Zone (AHZ) Map. PHZ and AHZ maps have not yet been produced for Turkey. To overcome deficiencies of these maps and compare the distribution of major forest tree species over these zones, data from 260 meteorological stations recorded during the period from 1975-2008 and 458144 forest stand-type polygon centroid data were used. PHZ and AHZ maps were created through the interpolation of meteorological data using the regularized spline with tension (RST) method. According to the interpolation results, there are 7 PHZs (4-10) and 8 AHZs (2-9) in Turkey. Finally, the distribution of $\mathbf{1 5}$ major forest tree species over these zones was investigated. The most commonly detected species were distributed among PHZs 5 and 10 coincided with Juniperus spp., Quercus spp. and Abies spp., and the species found between PHZs 5 and 10 were those exhibiting the most extensive distributions. Pinus brutia and Quercus spp. were found to be the most widely distributed species among the AHZs.

Keywords: Forest trees, Plant hardiness zones, Plant heat zones, Regularized spline with tension method, Turkey

\begin{abstract}
Introduction
Planting and growing an exotic species outside of its natural habitat presents a dilemma because it is unknown whether such a species will survive. Experts in fields addressing this issue (forest and agricultural engineers, horticulturists and landscape architects) have built up considerable knowledge about the species in their regions as a result of long-term observations. However, it is very difficult to predict whether a species that will be grown in a region for the first time will prosper or perish. Various restrictive factors, such as drought, insect and
\end{abstract}

$\square$ Department of Forest Engineering, Faculty of Forestry, Istanbul University, 34473 Bahçeköy, Istanbul (Turkey)

@, Osman Yalçin Yilmaz

(yilmazy@istanbul.edu.tr)

Received: Nov 25, 2011 - Accepted: Mar 27, 2012

Citation: Yilmaz OY, Tolunay D, 2012. Distribution of the major forest tree species in Turkey within spatially interpolated plant heat and hardiness zone maps. iForest 5: 83 92 [online 2012-04-30] URL: http://www. sisef.it/iforest/contents/?id=ifor0611-005

Communicated by: Marco Borghetti fungus damages, extreme heat and cold, soil wetness, day length, nutrient deficiencies, salinity and air pollution affect plant growth. Plants are very well adapted to the extreme conditions existing within their natural range of occurrence; however, they are likely to suffer when they are grown outside these regions.

Various approaches may be adopted in order to decide whether to use plants outside of their natural habitat. For example, in European forestry, the adaptation possibilities of species to newly planted areas are investigated by performing long-term provenance trials. Species-specific breeding or seed zones can also be utilized for this purpose. In addition, seed or plant materials can be transferred with minimum risk within a breeding zone (Johnson et al. 2004). Progeny tests, garden experiments and provenance trials are also used to produce breeding zone maps (Isik et al. 2000). Seed breeding zones are created by considering characteristics such as climate, vegetation, and elevation (Isik et al. 2000).

Climate is one of the most important factors affecting plant distribution. Seed or seedling transfer can be performed when the climatic characteristics of the growing region of a plant species are known. Climate classifications have been obtained using various climatic factors affecting plant growth. Bioclimatic classifications or indexes are used in studies on the distribution of plants, animals and ecosystems (Attorre et al. 2007). The most commonly used bioclimatic indices, mainly based on temperature and precipitation parameters, were developed by De Martonne (1927), Köppen (1936), Thornthwaite (1948), Bagnouls \& Gaussen (1957), and Rivas-Martinez (1996), as described by Attorre et al. (2007).

Hardiness zones have been used for many years to select species for use in plantations of exotic or ornamental species in North America. Additionally, it has been stated that cold hardiness zones could be used in performing seed transfer of economically important pine species in North America (Schmidtling 2001). Plant Hardiness Zones (PHZs) help determine under which environmental conditions plants can survive or be grown (Mckenney et al. 2007). For this reason, numerous systems have been generated to map the PHZs in North America. The most widely used of these is the USDA PHZ Map, which was generated based on mean extreme annual minimum temperatures (Cathey 1990). Although this system is referred to as a PHZ map, it is limited to cold resistance. The foundation of this system goes back to the map produced by Rehder (1927) using observations performed in the Arnold Arboretum (Wyman \& Flint 1967). The mean monthly extreme minimum temperatures, measured from various meteorological stations located in the US and Canada, were classified by Rehder using $5{ }^{\circ} \mathrm{F}$ (2.6$2.7^{\circ} \mathrm{C}$ ) intervals, and 7 PHZs were delineated. In the following years, another classification method, referred to as the Arnold Arboretum hardiness zones classification, was developed by Wyman (1938) and Wyman \& Flint (1967). Mean extreme annual minimum temperatures were used in this classification. Hardiness zones were designed using 5,10 and $15^{\circ} \mathrm{F}$ intervals, obtaining 10 distinct hardiness zones, and a PHZ map was constructed for the US. This map was revised in 1967 and 1971 (Wyman \& Flint 1967). The PHZs developed by the USDA are currently used for plant selection. In this classification system, 10 PHZs (1-10) were created with $10^{\circ} \mathrm{F}$ intervals. Zones 2 through 10 were separated into sub-zones $a$ and $b$, with $5^{\circ} \mathrm{F}$ intervals. The USDA PHZ map was created for the US in 1960 using this classification. In 1990, this map was revised, and an $11^{\text {th }}$ zone was added. This map was subsequently revised again, and the $12^{\text {th }}$ and the $13^{\text {th }}$ zones were added in 2012 (USDA 2012). PHZs for Canada and Mexico can also be found in the 1990 USDA map (Del Tredici 1990). These zones and the temperatures pertaining to them are reported in Tab. 1. Another similar map was created 
specifically for Canada in 1967 (Ouellet \& Sherk 1967a, 1967b, 1967c). The difference between this map and the USDA map is that 7 totally different climate variables (mean minimum temperature of the coldest month, frost-free period in days, rainfall from June through November, mean maximum temperature of the warmest month, rainfall in January, mean maximum snow depth, and maximum wind gust over 30 years) were used. In the Canadian map, the southern part of the country was separated into 11 different PHZs. This map was updated using thin-plate smoothing spline interpolation techniques (McKenney et al. 2001). However, this classification system is limited to relatively local use. In contrast, the USDA classification system for plant cold hardiness is currently widely used throughout the world. The reason this system is so extensively accepted worldwide is that the values of the extreme minimum temperatures under which plants can survive and grow have been observed and recorded for many years, and it is easy to obtain information concerning the cold hardiness zones of many plants from numerous books and records. Similarly, PHZ maps in which the mean extreme annual minimum temperatures are taken into account have been created for the entire world (Magarey et al. 2008), for Europe (Heinze \& Schreiber 1984, Swedish Fuchsia Society 2012), for Australia (Dawson 1991) and for China (Widrlechner 1997).

Although hardiness zones are generally useful for the selection of species to be used in long-term afforestation activities in a particular area/region, they are also commonly used for phytosanitary risk analysis (Magarey et al. 2008). Additionally, PHZ maps have been used for the interpretation of climate change. For example, after the USDA PHZ map developed for the US in 1990 was revised by the National Arbor Day Foundation (2006), it was observed that cold hardiness zones had shifted to some extent towards northern latitudes. Similarly, due to changing climatic conditions, changes in the PHZs of the revised Canadian map have particularly been observed in western Canada (McKenney et al. 2001). Furthermore, for plant material to be used effectively, plant adaptation regions have been delimited by combining ecoregion and hardiness zone classifications (Vogel et al. 2005).

In addition to plant cold hardiness zones, a plant heat hardiness zone classification system for the US was also created. In this system, the annual mean number of days with a maximum temperature $\geq 30{ }^{\circ} \mathrm{C}$ was used because above this threshold value plant proteins begin to degrade (Giddings \& Soto-Esparza 2005). The classification scheme for the cold and heat hardiness zones can be seen in Tab. 1. This hardiness classification system was developed by the American Hor-

Tab. 1 - Criteria used to classify USDA PHZ and AHS AHZ maps. (1): USDA (2012); (2): AHS (1997).

\begin{tabular}{|c|c|c|c|c|}
\hline \multirow{3}{*}{$\begin{array}{l}\text { USDA plant } \\
\text { hardiness zone }\end{array}$} & \multirow{2}{*}{\multicolumn{2}{|c|}{$\begin{array}{c}\text { Definition of USDA PHZ } \\
\begin{array}{c}\text { Mean extreme annual minimum } \\
\text { temperatures }^{(1)}\end{array}\end{array}$}} & \multicolumn{2}{|c|}{ Definition of AHS AHZ } \\
\hline & & & \multirow{2}{*}{$\begin{array}{l}\text { AHS plant heat } \\
\text { zone }\end{array}$} & \multirow{2}{*}{$\begin{array}{l}\text { Average number } \\
\text { of days per year } \\
\text { above } 30^{\circ} \mathrm{C}^{(2)}\end{array}$} \\
\hline & Fahrenheit $\left({ }^{\circ} \mathbf{F}\right)$ & Celsius $\left({ }^{\circ} \mathrm{C}\right)$ & & \\
\hline PHZ 1 & $>-50$ & $>-45.6$ & AHZ 1 & $<1$ \\
\hline PHZ 2 & $-50 \div-40$ & $-40.0 \div-45.5$ & AHZ 2 & $1 \div 7$ \\
\hline PHZ 3 & $-40 \div-30$ & $-34.5 \div-39.9$ & AHZ 3 & $>7 \div 14$ \\
\hline PHZ 4 & $-30 \div-20$ & $-28.9 \div-34.4$ & AHZ 4 & $>14 \div 30$ \\
\hline PHZ 5 & $-20 \div-10$ & $-23.4 \div-28.8$ & AHZ 5 & $>30 \div 45$ \\
\hline PHZ 6 & $-10 \div 0$ & $-17.8 \div-23.3$ & AHZ 6 & $>45 \div 60$ \\
\hline PHZ 7 & $0 \div 10$ & $-12.3 \div-17.7$ & AHZ 7 & $>60 \div 90$ \\
\hline PHZ 8 & $10 \div 20$ & $-6.7 \div-12.2$ & AHZ 8 & $>90 \div 120$ \\
\hline PHZ 9 & $20 \div 30$ & $-1.2 \div-6.6$ & AHZ 9 & $>120 \div 150$ \\
\hline PHZ 10 & $30 \div 40$ & $4.4 \div-1.1$ & AHZ 10 & $>150 \div 180$ \\
\hline PHZ 11 & $40 \div 50$ & $10.0 \div 4.5$ & AHZ 11 & $>180 \div 210$ \\
\hline PHZ 12 & $50 \div 60$ & $15.6 \div 10.1$ & AHZ 12 & $>210$ \\
\hline PHZ 13 & $60 \div 70$ & $21.1 \div 15.7$ & - & - \\
\hline
\end{tabular}

ticultural Society (AHS), and it is known as the AHS Plant Heat Zones (AHZ) system. The AHS plant heat hardiness classification system is relatively new and has been commonly used following the publication the US AHZ map in 1997 (AHS 1997). A similar Mexican AHZ map was developed in 2005 (Giddings \& Soto-Esparza 2005). Plant cold hardiness zones indicate the most extreme winter conditions, whereas plant heat hardiness zones indicate the most extreme summer conditions (Giddings \& Soto-Esparza 2005). Although records concerning plant cold hardiness zones have long been maintained, records concerning plant heat hardiness zones are rare.

Turkey's climate is generally characterized as belonging to the Mediterranean macro-climate zone and varies considerably due to geomorphology (e.g., mountains extending parallel to the shore, high mountainous areas). As an example, Turkey's Aegean and Mediterranean coasts exhibit a temperate climate with a highly seasonal precipitation regime, while the Black Sea coast presents a uniformly rainy and humid temperate climate. A continental semi-arid climate type is dominant in Central and Eastern Anatolia and Central Thrace away from sea effects (Erinc 1969, Türkes \& Tatli 2009). The mean temperature is $12.81{ }^{\circ} \mathrm{C}$, according to long-term observations. Temperatures have continuously increased over the last 15 years, and the average temperature was $15.20^{\circ} \mathrm{C}$ in 2010 . In addition, the mean total precipitation is approximately $640 \mathrm{~mm}$ annually (TSMS 2011).

The forested area of Turkey covers approximately 21.2 million ha. However, almost half of this forest area shows canopy cover values of less than $10 \%$, and these areas are considered to be unproductive. A nationwide afforestation initiative was undertaken over approximately 2 million ha until 2006 to properly forest these unproductive forests, open areas and areas that had been burned down (MEF 2007). An afforestation and erosion control action plan was developed for the period 2008-2012 to forest the unproductive forest areas and to rehabilitate them (MEF 2007). This initiative is aimed at carrying out the afforestation of over 252000 ha in a 5-year period. Additionally, afforestation and rehabilitation of unproductive forest areas are presented as important strategies for combating climate change according to the Turkish National Climate Change Strategy Document (MEF 2010).

Breeding zone maps in Turkey are available for Pinus brutia, $P$. nigra, and $P$. sylvestris (Atalay 1977), Picea orientalis (Atalay 1984), Cedrus libani (Atalay 1987), and Fagus orientalis (Atalay 1992). However, these maps have been only used for seed transfer within the natural range of these species. Provenance trials and progeny tests have been performed with some fast growing natural and exotic forest tree species. However, these efforts have remained nearly local. No accuracy tests have been carried out for most species-specific seed transfer zones prepared using geographic and climatic parameters in Turkey. In this context, Isik et al. (2000) emphasized that the provenance experiments they conducted for P. brutia did not support the reported seed transfer zones of this species. Many factors affect the growth of forest tree species in Turkey, and the most limiting is summer drought. Extremely low temperatures, soil properties and air humidity are also limiting factors (Isik et al. 2000). Growth-limiting factors can be diverse locally due to the great climate variability of Turkey. This problem can be solved by carrying out seed and seedling transfer via breeding zones in the natural distribution areas of forest trees. However, growing forest tree species outside 


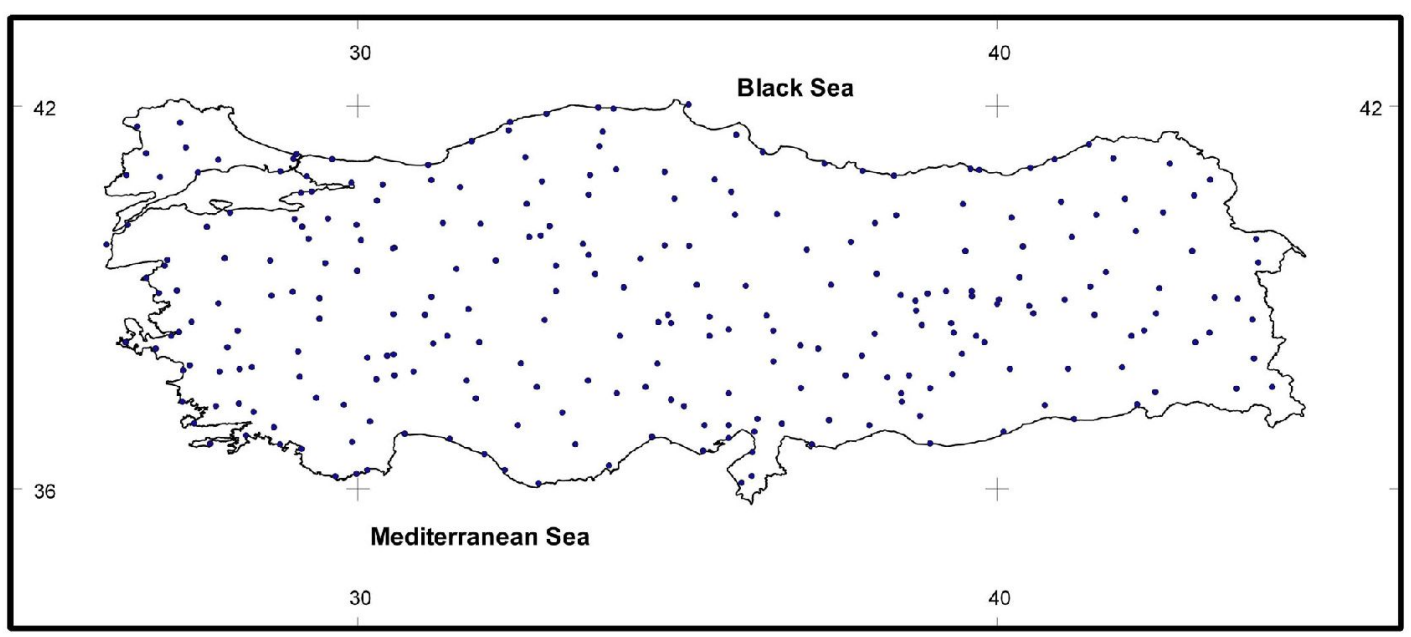

Fig. 1 - Locations of the meteorological stations in Turkey used in the study.

of their natural distribution areas has been a perpetual problem in Turkey.

In particular, conifer species such as Pinus brutia, $P$. nigra, $P$. sylvestris, $P$. pinea and Cedrus libani, are extensively used in afforestation programs. These species are often planted outside the conditions of their natural range, resulting in their suffering from summer drought, extreme cold or insect damage in some cases. For example, in $\mathrm{Ca}$ labrian pine plantations implemented in northern and central Thrace, considerable tree losses were reported during the 19851986 winter frosts (Tolunay 1999). No AHZ map currently exists for Turkey, whereas PHZs are noted superficially in the map by Heinze \& Schreiber (1984) for the European continent.

In this study, we aimed first to generate plant cold and heat hardiness zone maps for Turkey through interpolation of meteorological data and then to determine the cold and heat hardiness zone distribution statistics of the major forest tree species of Turkey. The developed hardiness maps and the information obtained from these statistics should be helpful in the selection of tree species to be used in plantations.

\section{Materials and methods}

\section{Meteorological data}

In this study, measurements of minimum monthly temperature values and the annual number of days with a maximum temperature $\geq 30{ }^{\circ} \mathrm{C}$ recorded from 280 meteorological stations during the period from 19752008 were used. The locations of the stations are displayed in Fig. 1. The lowest minimum monthly temperatures used in determining the PHZs were generally found to occur in the winter months of December, January, and February. If the records for these particular months were missing, the associated year was excluded from the calculation of the mean extreme annual minimum temperatures for the 34-year study period. Stations with less than 20 years of data were also omitted from the analysis, and thus, the interpolation results were obtained using the data from 260 stations.

A similar approach was applied for constructing the AHZs. First, raw monthly data pertaining to the number of days with a maximum temperature $\geq 30{ }^{\circ} \mathrm{C}$ were examined. It was observed that the days with a maximum temperature $\geq 30{ }^{\circ} \mathrm{C}$ were mainly clustered between the months of March and November. However, the monthly distribution of the days with a maximum temperature $\geq 30{ }^{\circ} \mathrm{C}$ was observed to vary greatly depending upon the meteorological station from which the data were acquired. It was found that in the June to August period in particular, temperature values reached well over $30^{\circ} \mathrm{C}$. Years in which no records had been collected for the June to August period were excluded from the calculation of the annual mean number of days with a maximum temperature $\geq 30{ }^{\circ} \mathrm{C}$. Again, stations with less than 20 years of records within the whole 34-year period were excluded from the analysis. Thus, data from a total of 250 stations were included in the interpolation. For each station, after the mean annual extreme minimum temperatures and annual mean number of days with a maximum temperature $\geq 30{ }^{\circ} \mathrm{C}$ were calculated, we proceeded to constructing and mapping the plant cold and heat hardiness zones for each station. The values used in the classification of the plant cold and heat hardiness zones are shown in Tab. 1. There are 13 zones in the USDA PHZ map, subdivided into $a$ and $b$ sub-zones (USDA 2012). However, no

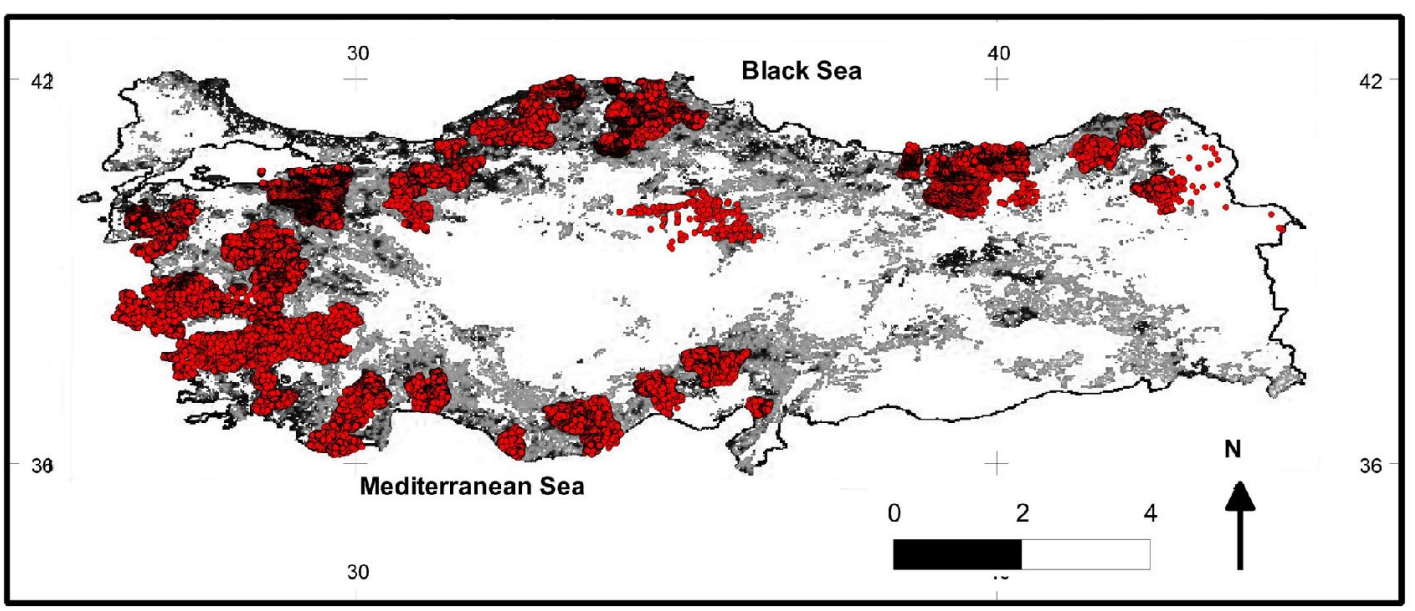

Fig. 2 - Forest map of Turkey and the locations of the forest tree data used in the study (red points). 
(a)

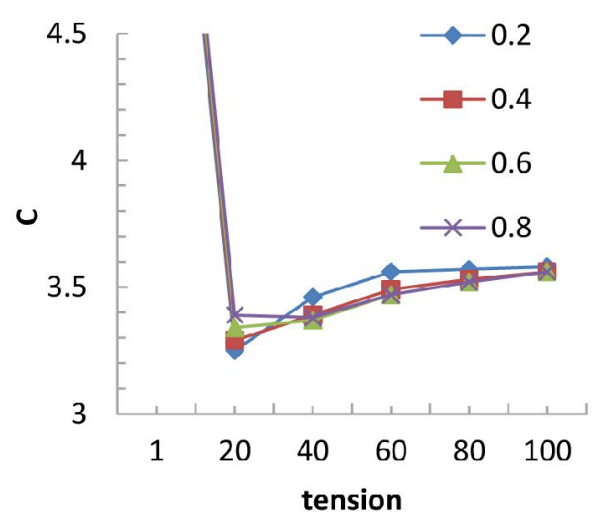

(b) 26

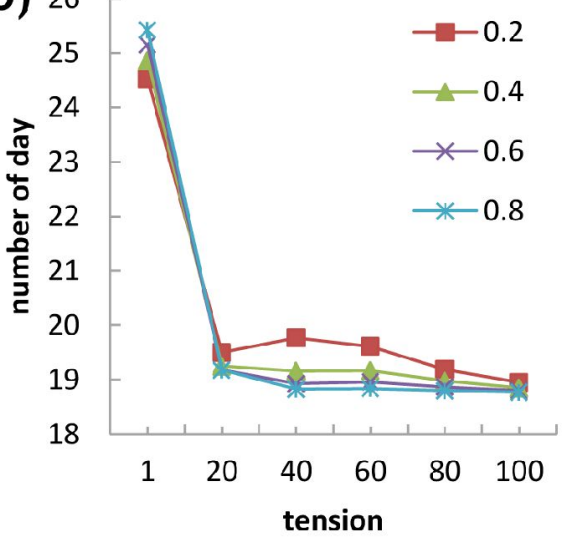

Fig. 3 - RMSE of cross-validation with different tension and smoothing values a) for mean extreme annual minimum temperatures and $b$ ) for the annual mean number of days with a maximum temperature $\geq 30^{\circ} \mathrm{C}$.

such detailed classification can be found in other maps used in different parts of the world (Heinze \& Schreiber 1984, Dawson 1991, Widrlechner 1997), as no in-depth re-

Tab. 2 - Interpolation parameters used in the $\mathrm{PHZ}$ and AHZ maps produced in this study.

\begin{tabular}{cc}
\hline segmax/ & Tension/ \\
npmin & smoothing \\
\hline $15 / 30$ & $20-40-60-80-100 /$ \\
& $0.2-0.4-0.6-0.8$ \\
$30 / 60$ & $20-40-60-80-100 /$ \\
& $0.2-0.4-0.6-0.8$ \\
$60 / 120$ & $20-40-60-80-100 /$ \\
& $0.2-0.4-0.6-0.8$ \\
$120 / 240$ & $20-40-60-80-100 /$ \\
& $0.2-0.4-0.6-0.8$ \\
\hline
\end{tabular}

search has been carried out on hardiness zones outside US. Therefore, the sub-zones described above were not used in this study.

\section{Forest tree data}

After of the PHZ and AHZ maps were created, the zones where major tree species can be found in Turkish forests were determined. In this stage, 458144 stand-type polygon centroid data acquired from the General Directorate of Forestry (GDF) were employed (Fig. 2).

\section{Generation of plant hardiness zone maps}

To produce the PHZ and AHZ maps, meteorological point-based data were converted to continuous surface data using the regularized spline with tension (RST) method

Tab. 3 - RMSE values of the PHZ maps produced with different parameters.

\begin{tabular}{|c|c|c|c|c|}
\hline \multirow{2}{*}{ Tension_smoothing } & \multicolumn{4}{|c|}{ segmax_npmin } \\
\hline & 15_30 & 30_60 & 60_120 & 120_240 \\
\hline $20 \_0.2$ & 0.77 & 1.13 & 1.77 & 2.22 \\
\hline $40 \_0.2$ & 0.37 & 0.52 & 1.07 & 1.36 \\
\hline $60 \_0.2$ & 0.28 & 0.35 & 0.89 & 1.04 \\
\hline 80_0.2 & 0.23 & 0.28 & 0.83 & 0.91 \\
\hline 100_0.2 & 0.20 & 0.79 & 0.85 & 0.85 \\
\hline $20 \_0.4$ & 1.26 & 1.58 & 1.99 & 2.40 \\
\hline $40 \_0.4$ & 0.93 & 1.06 & 1.27 & 1.58 \\
\hline $60 \_0.4$ & 0.86 & 0.92 & 1.03 & 1.22 \\
\hline 80_0.4 & 0.83 & 0.87 & 0.93 & 1.06 \\
\hline $100 \_0.4$ & 0.81 & 0.84 & 0.97 & 0.97 \\
\hline 20_0.6 & 1.41 & 1.75 & 2.13 & 2.52 \\
\hline 40_0.6 & 1.03 & 1.19 & 1.42 & 1.75 \\
\hline $60 \_0.6$ & 0.93 & 1.02 & 1.15 & 1.37 \\
\hline 80_0.6 & 0.89 & 0.95 & 1.04 & 1.19 \\
\hline 100_0.6 & 0.87 & 0.91 & 1.08 & 1.08 \\
\hline $20 \_0.8$ & 1.54 & 1.87 & 2.24 & 2.62 \\
\hline $40 \_0.8$ & 1.13 & 1.30 & 1.55 & 1.87 \\
\hline $60 \_0.8$ & 1.01 & 1.12 & 1.27 & 1.50 \\
\hline 80_0.8 & 0.96 & 1.03 & 1.14 & 1.30 \\
\hline $100 \_0.8$ & 0.93 & 0.98 & 1.19 & 1.19 \\
\hline
\end{tabular}

(Mitasova et al. 1995, Mitas \& Mitasova 1999). To determine appropriate prediction parameters (tension, the number of points in the segment - segmax, the number of points used for interpolation within the segment and its neighborhood - npmin, smoothing) for the RST method (Neteler \& Mitasova 2002), different tension and smoothing parameters were tested by cross-validation. Initially, the default values of the method (npmin $=300$ and segmax $=40$ ) were used. The number of points in a segment is controlled by segmax, and the number of points used for interpolation (within the segment and its neighborhood) is controlled by npmin (Neteler \& Mitasova 2002). According to the cross-validation results, if the predictions were carried out with a tension of 20 and 0.2 smoothing for the mean extreme annual minimum temperatures and with a tension of 100 and 0.8 smoothing for the annual mean number of days with a maximum temperature $\geq 30{ }^{\circ} \mathrm{C}$, the minimum RMSE (Root Mean Square Error) could be acquired, and the predictions could further decrease the error rate (Fig. 3).

According to the results of the cross-validation method, it was found that the maps for the mean extreme annual minimum temperatures and mean annual number of days with a maximum temperature $\geq 30{ }^{\circ} \mathrm{C}$ were excessively generalized, and some local details were not shown when using parameters likely to give the least error. This may be likely due to the limited number of pinpoint values (meteorological stations) on the map and/or their large intervening distance (average $70 \mathrm{~km}$ ). To reduce the effect of distant stations and to produce a much more detailed map, numerous interpolation maps with various tension, smoothing, npmin and segmax parameters were produced (Tab. 2). Maps showing the lowest RMSE values were visually checked depending on station average values. Plant cold and heat hardiness zone maps were then produced using the USDA PHZ and AHS AHZ classifications. Finally, the raster cell values from the obtained PHZ and AHZ maps were loaded into the polygon centroids of a forest stand type attribute table (Grass Development Team 2008). The zones showing the distribution of 15 tree species were determined through queries performed on the vector data.

\section{Results}

\section{Validation test of maps}

Goodness-of-fit of the maps obtained was tested by comparing the predicted and observed values for mean extreme annual minimum temperatures in each meteo station. Although maps obtained using the parameters 30 npmin 15 segmax and 60 npmin $30 \mathrm{seg}$ max showed rather low RMSEs (less than $0.5^{\circ} \mathrm{C}$ ), they were not used because these 
maps exhibited strip-like patterns. The next best-fitting map (RMSE $<1{ }^{\circ} \mathrm{C}$ ), obtained using the parameters 80 tension, 0.2 smoothing, 120 npmin and 60 segmax, was chosen for the construction of the plant cold hardiness zone map (Tab. 3).

Analogously, predicted annual mean number of days with a maximum temperature $\geq$ $30{ }^{\circ} \mathrm{C}$ were compared to the observed (station) values for each produced map. The results obtained using the parameters 80 or 100 tension, 0.2 smoothing, 15 segmax, and 30 npmin and 100 tension, 0.2 smoothing, 30 segmax, and 60 npmin showed the lowest RMSEs, but the corresponding maps exhibited strip-like patterns. For this reason, the map produced using the parameters 80 tension, 0.2 smoothing, 60 segmax and 120 npmin (RMSE $=1.65^{\circ} \mathrm{C}$ ) was chosen for the construction of the plant heat hardiness zone map (Tab. 4).

\section{Plant cold and heat hardiness zones in Turkey}

The meteorological stations showing the lowest mean extreme annual minimum temperatures and the highest mean extreme annual minimum temperatures in Turkey were those of Agri and Kas $\left(-32.89{ }^{\circ} \mathrm{C}\right.$ and 2.80 ${ }^{\circ} \mathrm{C}$, respectively - Tab. 5). According to the generated PHZ maps (Fig. 4), it can clearly be concluded that not all of the USDA PHZs are present in Turkey. A total of 7 PHZs, with mean extreme annual minimum temperatures ranging between $-34.4{ }^{\circ} \mathrm{C}$ and $4.4{ }^{\circ} \mathrm{C}$, can be observed. These 7 zones are located between PHZs 4 and 10. In the central and eastern Anatolian region, where the continental climate is dominant, 4 to $7 \mathrm{PHZs}$ are present (Fig. 4). The $10^{\text {th }} \mathrm{PHZ}$, in which the mean extreme annual minimum temperatures are higher, is located on the Mediterranean coastline. Other coastline regions are situated in the $9^{\text {th }} \mathrm{PHZ}$. A considerable portion $(32.99 \%)$ of the country is found in PHZ 7 In contrast, PHZ 4 covers the smallest area (0.38\% - Tab. 6).

The Zonguldak stations had the fewest (4.56) annual mean number of days with a maximum temperature $\geq 30{ }^{\circ} \mathrm{C}$. The maximum value for this parameter (144.24 days year $\left.^{-1}\right)$ was registered at the Cizre station (Tab. 5). Based on measurements obtained from the meteorological stations, only AHZ categories 2-9 out of the 12 previously reported are present in Turkey (Fig. 5). AHZ 5 covers the largest area $(33.22 \%)$, with an annual mean number of days with a maximum temperature $\geq 30{ }^{\circ} \mathrm{C}$ ranging from 30 to 45 . AHZ 2, in which the days with temperatures $\geq 30{ }^{\circ} \mathrm{C}$ ranges from 1 to 7 , corresponds to $0.18 \%$ of the land area (Tab. 6). In contrast, AHZ 9, which was associated with an annual mean of more than 120 days with a maximum temperature $\geq 30{ }^{\circ} \mathrm{C}$, corresponds to $2.18 \%$ of the land area.

Tab. 4 - RMSE values of the AHZ maps produced, using different parameters.

\begin{tabular}{ccccc}
\hline \multirow{2}{*}{ Tension_smoothing } & \multicolumn{4}{c}{ segmax_npmin } \\
\cline { 2 - 5 } & $\mathbf{1 5 \_ 3 0}$ & $\mathbf{3 0 \_ 6 0}$ & $\mathbf{6 0 \_ 1 2 0}$ & 120_240 \\
\hline 20_0.2 & 3.97 & 6.36 & 9.32 & 12.44 \\
40_0.2 & 1.64 & 2.50 & 4.01 & 6.36 \\
60_0.2 & 1.11 & 1.55 & 2.32 & 3.70 \\
80_0.2 & 0.90 & 1.18 & 1.65 & 2.50 \\
100_0.2 & 0.79 & 0.99 & 1.90 & 1.90 \\
20_0.4 & 5.53 & 7.95 & 10.70 & 13.41 \\
40_0.4 & 2.75 & 3.85 & 5.56 & 7.93 \\
60_0.4 & 2.01 & 2.64 & 3.62 & 5.22 \\
80_0.4 & 1.67 & 2.11 & 2.77 & 3.85 \\
100_0.4 & 1.48 & 1.81 & 3.09 & 3.09 \\
20_0.6 & 6.62 & 8.97 & 11.53 & 13.97 \\
40_0.6 & 3.65 & 4.87 & 6.64 & 8.95 \\
60_0.6 & 2.77 & 3.52 & 4.62 & 6.30 \\
80_0.6 & 2.36 & 2.89 & 3.67 & 4.87 \\
100_0.6 & 2.11 & 2.53 & 4.04 & 4.04 \\
20_0.8 & 7.45 & 9.72 & 12.12 & 14.37 \\
40_0.8 & 4.42 & 5.70 & 7.47 & 9.70 \\
60_0.8 & 3.45 & 4.28 & 5.44 & 7.14 \\
80_0.8 & 2.97 & 3.59 & 4.44 & 5.69 \\
$100 \_0.8$ & 2.69 & 3.18 & 4.83 & 4.83 \\
\hline
\end{tabular}

Tab. 5 - Summary statistics for the observed and interpolated mean extreme annual minimum temperatures and annual mean number of days with a maximum temperature $\geq 30{ }^{\circ} \mathrm{C}$ during the period from 1975-2008 in Turkey (interpolated values in parenthesis).

\begin{tabular}{lcccc}
\hline \multicolumn{1}{c}{ Parameters } & Mean & Minimum & Maximum & $\begin{array}{c}\text { Standard } \\
\text { deviation }\end{array}$ \\
\hline Mean extreme annual & -11.10 & -32.89 (Agri) & $2.80($ Kas $)$ & 7.80 \\
minimum temperatures & $(-11.22)$ & $(-32.48)$ & $(2.45)$ & $(7.60)$ \\
Annual mean number of & 52.54 & 4.56 (Zonguldak) & 144.24 (Cizre) & 30.70 \\
days with a maximum & $(52.88)$ & $(5.74)$ & $(141.35)$ & $(30.12)$
\end{tabular}

temperature $>30^{\circ} \mathrm{C}$

Distribution of forest trees in plant cold hardiness zones

None of the centroids of the polygons for the 458144 investigated stand types was located in PHZ 4. Juniperus spp., Quercus spp. and Abies spp. were found to be the most widely distributed species across PHZs.

These particular species were found between PHZ 5 and 10. The narrowest distribution was showed by Liquidambar orientalis, which was found only in PHZ 9. Exotic Eucalyptus species were planted in PHZs 7 to 10 . Other species, such as $P$. orientalis and P. sylvestris, existed in PHZs 5 to 9; P. bru-

Tab. 6 - The distribution of land in Turkey according to the PHZ and AHZ.

\begin{tabular}{cccccc}
\hline \multicolumn{2}{c}{ USDA Plant Hardiness Zones } & \multicolumn{3}{c}{ AHS Plant Heat Zones } \\
\hline \multirow{2}{*}{ Zones } & $\begin{array}{c}\text { Area } \\
(\mathbf{1 0 0 0} \text { ha) }\end{array}$ & $\mathbf{\%}$ & Zones & $\begin{array}{c}\text { Area } \\
(\mathbf{1 0 0 0} \text { ha })\end{array}$ & \% \\
\hline 1 & - & - & 1 & - & - \\
2 & - & - & 2 & 137.11 & 0.18 \\
3 & - & - & 3 & 1205.27 & 1.55 \\
4 & 298.8 & 0.38 & 4 & 17141.64 & 22.02 \\
5 & 4793.63 & 6.16 & 5 & 25864.88 & 33.22 \\
6 & 8362.92 & 10.74 & 6 & 13636.91 & 17.51 \\
7 & 25685.62 & 32.99 & 7 & 11501.15 & 14.77 \\
8 & 17954.34 & 23.06 & 8 & 6674.85 & 8.57 \\
9 & 18272.86 & 23.47 & 9 & 1697.83 & 2.18 \\
10 & 2491.45 & 3.2 & 10 & - & - \\
11 & - & - & 11 & - & - \\
12 & - & - & 12 & - & - \\
13 & - & - & - & - & - \\
Total & 77859.62 & 100 & - & 77859.62 & 100 \\
\hline
\end{tabular}




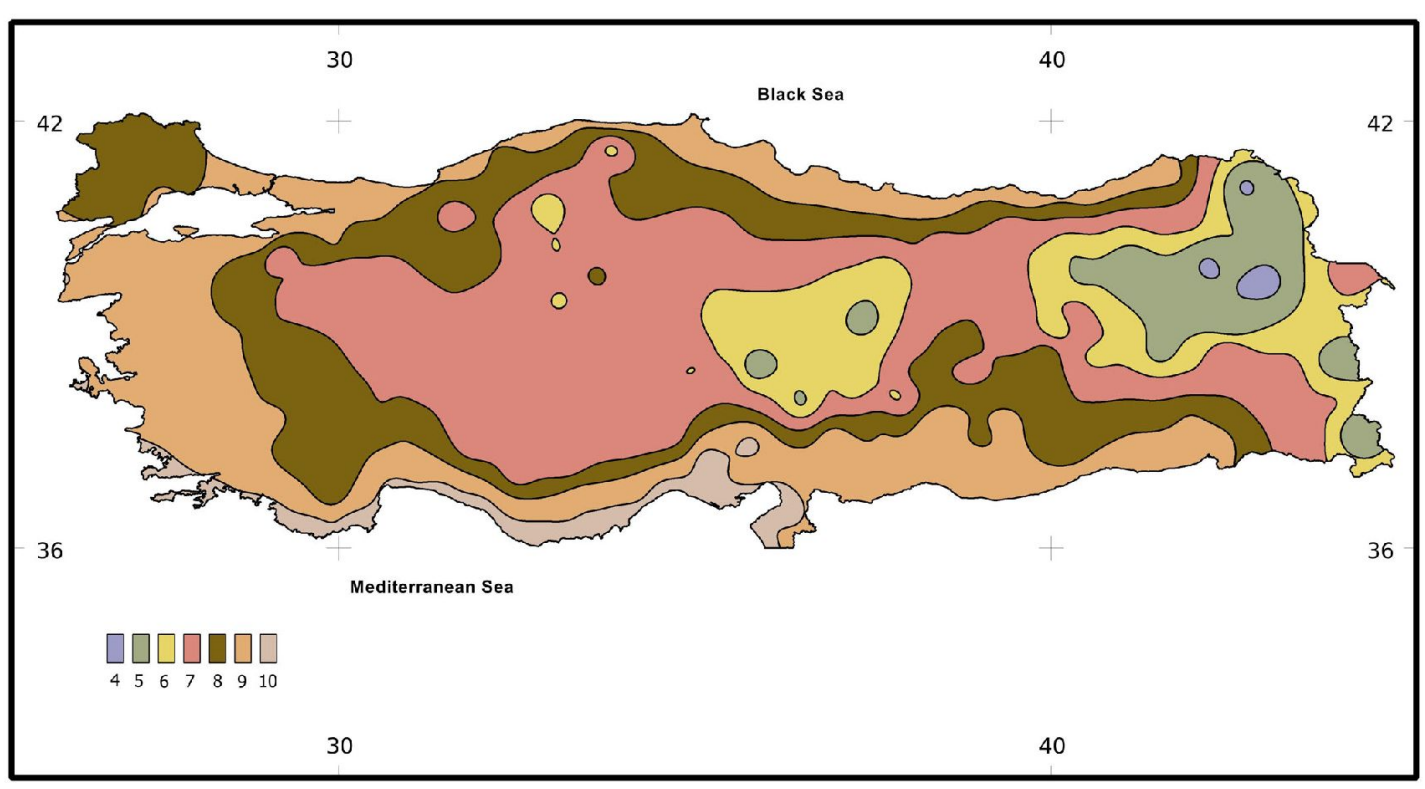

Fig. 4 - USDA Plant Hardiness Zone (PHZ) map of Turkey.

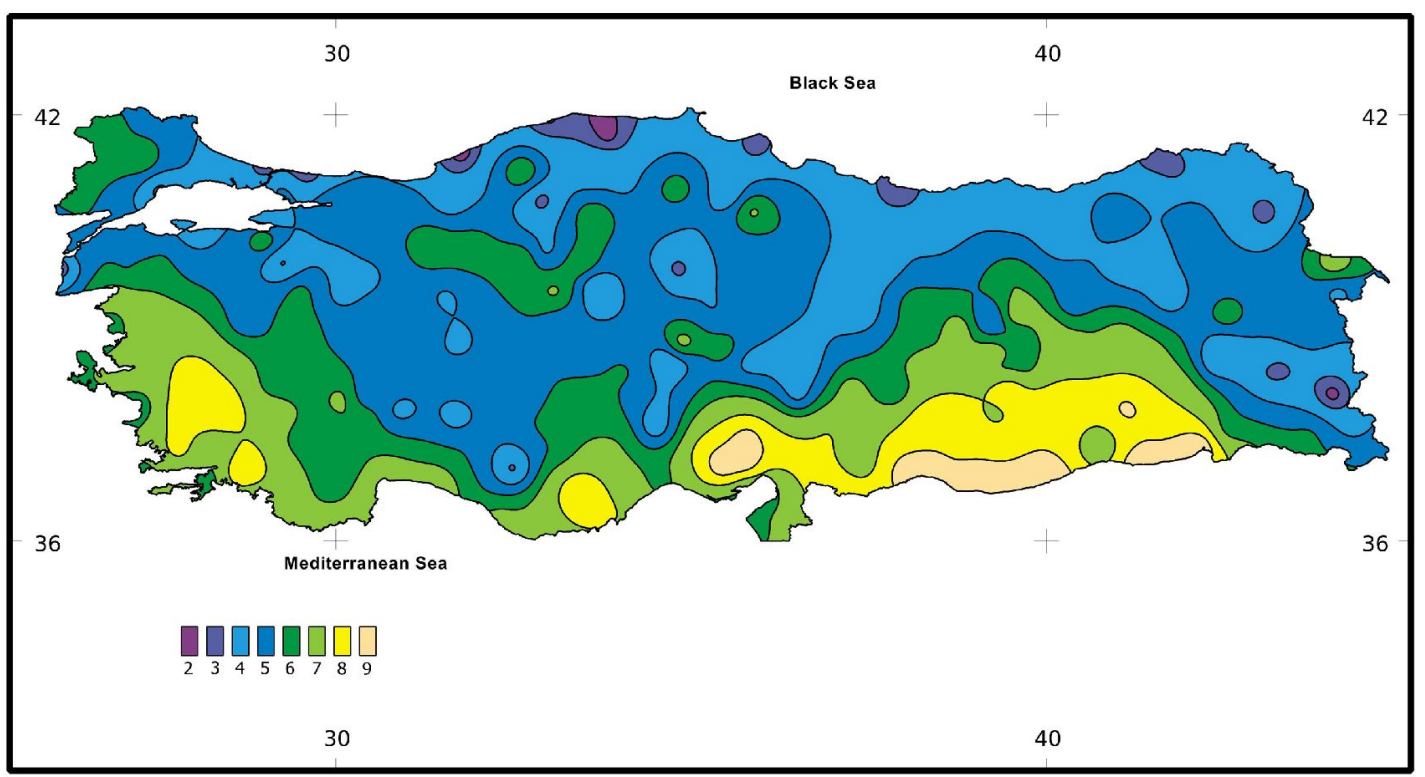

Fig. 5 - AHS Plant Heat Zone (AHZ) map of Turkey.

Tab. 7 - USDA PHZs in which the main forest tree species are distributed in Turkey.

\begin{tabular}{|c|c|c|c|c|c|c|c|}
\hline \multirow{2}{*}{ Species } & \multicolumn{6}{|c|}{ USDA Plant Hardiness Zones } & \multirow{2}{*}{ Total } \\
\hline & 5 & 6 & 7 & 8 & 9 & 10 & \\
\hline$\overline{\text { Pinus brutia }}$ & - & - & 2395 & 28381 & 107132 & 18165 & 156073 \\
\hline Pinus nigra & - & 76 & 15353 & 75223 & 36115 & 340 & 127107 \\
\hline Pinus sylvestris & 3082 & 4732 & 16970 & 14596 & 753 & - & 40133 \\
\hline Abies spp. & 84 & 502 & 3713 & 6356 & 2542 & 33 & 13230 \\
\hline Picea orientalis & 9 & 756 & 3493 & 8238 & 749 & - & 13245 \\
\hline Juniperus spp. & 53 & 106 & 1357 & 5652 & 4942 & 284 & 12394 \\
\hline Cedrus libani & - & - & 4 & 1891 & 4005 & 1636 & 7536 \\
\hline Pinus pinea & - & - & 4 & 120 & 2926 & 245 & 3295 \\
\hline Quercus spp. & 19 & 372 & 7801 & 24099 & 1369 & 616 & 52276 \\
\hline Fagus orientalis & - & 8 & 3638 & 14442 & 7402 & 187 & 25677 \\
\hline Carpinus spp. & - & - & 141 & 441 & 461 & - & 1043 \\
\hline Alnus spp. & - & - & 4 & 1304 & 1804 & - & 3112 \\
\hline Castanea sativa & - & - & 48 & 942 & 1376 & - & 2366 \\
\hline Eucalyptus spp. & - & - & 19 & 207 & 350 & 27 & 603 \\
\hline Liquidambar orientalis & - & - & - & - & 54 & - & 54 \\
\hline Total & 3247 & 6552 & 5494 & 181892 & 189980 & 21533 & 458144 \\
\hline
\end{tabular}


Tab. 8 - AHZs in which the main forest tree species are distributed in Turkey.

\begin{tabular}{|c|c|c|c|c|c|c|c|c|c|}
\hline \multirow{2}{*}{ Species } & \multicolumn{8}{|c|}{ AHS Plant Heat Zones } & \multirow{2}{*}{ Total } \\
\hline & 2 & 3 & 4 & 5 & 6 & 7 & 8 & 9 & \\
\hline Pinus brutia & 2 & 21 & 3508 & 1984 & 31967 & 54033 & 45753 & 1805 & 156073 \\
\hline Pinus nigra & 4 & 1053 & 24861 & 5048 & 26679 & 13481 & 10549 & - & 127107 \\
\hline Pinus sylvestris & 19 & 454 & 18421 & 20667 & 572 & - & - & - & 40133 \\
\hline Abies spp. & 19 & 1022 & 6835 & 2635 & 1133 & 1111 & 475 & - & 1323 \\
\hline Picea orientalis & - & - & 13238 & 7 & - & - & - & - & 13245 \\
\hline Juniperus spp. & - & 13 & 741 & 2023 & 4796 & 3006 & 1761 & - & 12394 \\
\hline Cedrus libani & - & - & 3 & 43 & 2485 & 4469 & 536 & - & 7536 \\
\hline Pinus pinea & - & -- & 111 & 288 & 411 & 965 & 1520 & - & 3295 \\
\hline Quercus spp. & 43 & 1794 & 12661 & 18525 & 10246 & 4635 & 4289 & 83 & 52276 \\
\hline Fagus orientalis & 91 & 3181 & 14896 & 6036 & 902 & 447 & 124 & - & 25677 \\
\hline Carpinus spp. & - & 155 & 576 & 258 & 17 & 31 & 6 & - & 1043 \\
\hline Alnus spp. & - & - & 3107 & 5 & - & - & - & - & 3112 \\
\hline Castanea sativa & 12 & 295 & 1906 & 56 & 14 & 10 & 73 & - & 2366 \\
\hline Eucalyptus spp. & - & - & 51 & 185 & 176 & 143 & 48 & - & 603 \\
\hline Liquidambar orientalis & - & - & - & - & - & 6 & 48 & - & 54 \\
\hline Total & 190 & 7988 & 100915 & 120192 & 79398 & 82391 & 65182 & 1888 & 458144 \\
\hline
\end{tabular}

Tab. 9 - Comparison of the PHZ and AHZ values determined for some of the forest tree species in Turkey with those from other sources: (a) Cheers (1999); (b) Krüssmann (1984, 1985a, 1985b, 1986); (c) AHS (2005, 2006, 2008, 2010).

\begin{tabular}{|c|c|c|c|c|c|}
\hline \multirow[b]{2}{*}{ Species } & \multicolumn{3}{|c|}{ USDA Plant Hardiness Zone (PHZ) } & \multicolumn{2}{|c|}{ AHS Plant Heat Zone (AHZ) } \\
\hline & Cheers $^{(a)}$ & Krüssmann $^{(\mathbf{b})}$ & This study & $\begin{array}{l}\text { American } \\
\text { Gardener }^{(\mathfrak{c})}\end{array}$ & This study \\
\hline Abies nordmanniana & $4-9$ & 5 & $5-10$ & - & $8-2$ \\
\hline Abies cilicica & - & 6 & - & - & - \\
\hline Abies equitrojani & - & 6 & - & - & - \\
\hline $\begin{array}{l}\text { Abies nordmanniana subsp. bornmulle- } \\
\text { riana }\end{array}$ & - & 6 & - & - & - \\
\hline Cedrus libani & $6-9$ & 7 & $7-10$ & - & $8-4$ \\
\hline Juniperus communis & $2-9$ & - & $5-10$ & $6-1$ & $8-3$ \\
\hline Juniperus excelsa & - & 7 & - & - & - \\
\hline Juniperus foetidissima & - & 9 & - & - & - \\
\hline Juniperus oxycedrus & - & 9 & - & - & - \\
\hline Juniperus phoenicea & - & $8-9$ & - & - & - \\
\hline Juniperus sabina & $3-9$ & $3-7$ & - & $7-1$ & - \\
\hline Picea orientalis & $3-9$ & 5 & $5-9$ & $8-1$ & $5-4$ \\
\hline Pinus brutia & - & 8 & $7-10$ & - & $9-2$ \\
\hline Pinus nigra & $4-9$ & 4 & $6-10$ & - & $8-2$ \\
\hline Pinus pinea & $8-10$ & - & $7-10$ & - & $8-4$ \\
\hline Pinus sylvestris & $4-9$ & 5 & $5-9$ & $7-1$ & $6-2$ \\
\hline Alnus glutinosa & $4-9$ & 6 & $7-9$ & - & $5-4$ \\
\hline Alnus orientalis & $7-10$ & 6 & - & - & - \\
\hline Carpinus betulus & $6-9$ & 5 & $7-9$ & $8-1$ & $8-3$ \\
\hline Carpinus orientalis & $6-9$ & 6 & - & - & - \\
\hline Castanea sativa & $5-9$ & 6 & $7-9$ & - & $8-2$ \\
\hline Eucalyptus camaldulensis & $9-12$ & - & $7-10$ & - & $8-4$ \\
\hline Eucalyptus grandis & $10-11$ & - & - & - & - \\
\hline Fagus orientalis & $5-10$ & 6 & $6-10$ & - & $8-2$ \\
\hline Liqiudambar orientalis & $8-11$ & - & 9 & - & $8-7$ \\
\hline Quercus cerris & $7-10$ & 7 & $5-10$ & - & $9-2$ \\
\hline Quercus coccifera & - & 9 & - & - & - \\
\hline Quercus frainetto & - & 6 & - & - & - \\
\hline Quercus ilex & $7-10$ & 8 & - & - & - \\
\hline Quercus infectoria & - & 9 & - & - & - \\
\hline Quercus libani & - & 7 & - & - & - \\
\hline Quercus macranthera & - & 6 & - & - & - \\
\hline Quercus petraea & $5-9$ & 5 & - & - & - \\
\hline Quercus pontica & - & 6 & - & - & - \\
\hline Quercus pubescens & - & 7 & - & - & - \\
\hline Quercus robur & $3-10$ & 5 & - & - & - \\
\hline Quercus trojana & - & 8 & - & - & - \\
\hline
\end{tabular}


tia, C. libani, P. pinea, were found in PHZs 7 to 10 ; and $P$. nigra and $F$. orientalis were observed in PHZs 6 to 10. It was found that Castanea sativa, Alnus spp. and Carpinus spp. were located in PHZs 7, 8 and 9, in which the mean extreme annual minimum temperatures were less than $-6.6{ }^{\circ} \mathrm{C}$. Additionally, differences were found among the PHZs where the investigated tree species were most densely distributed. $P$. sylvestris was predominantly found in PHZ 7. In contrast, $P$. nigra, $P$. orientalis, Abies spp., Juniperus spp., F. orientalis and Quercus spp. inhabited PHZ 8 extensively. All of the remaining investigated species were mainly linked to PHZ 9 (Tab. 7).

\section{Distribution of forest trees in plant heat hardiness zones}

As for heat hardiness zones associated with the forest trees in Turkey, none of the 458144 centroids obtained was located in AHZ 1. Among the investigated forest species, the annual mean number of days with a maximum temperature $\geq 30{ }^{\circ} \mathrm{C}$ ranged from 2 to 150 in the distribution area of $P$. brutia and Quercus spp., and these species were present in every AHZ zone from 2 to 9 . After $P$. brutia and Quercus spp., the most widely abundant species were $P$. nigra, Abies spp. Fagus orientalis and $C$. sativa, which were observed in AHZs 2 to 8. The narrowest distribution was that of Liquidambar orientalis, which was only found in AHZs 7 and 8 , where the average number of days with a temperature $\geq 30{ }^{\circ} \mathrm{C}$ was more than 60 . The plant heat hardiness zones in which the investigated species were predominantly found varied considerably. Abies spp., P. orientalis, $F$. orientalis, C. sativa, Alnus spp. and Carpinus spp. were extensively encountered in AHZ 4, while $P$. nigra, $P$. sylvestris, Quercus spp. and Eucalyptus spp. were mainly located in AHZ 5, Juniperus spp. in AHZ 6, P. brutia and C. libani in AHZ 7 , and $P$. pinea and $L$. orientalis in AHZ 8 (Tab. 8).

\section{Discussion}

\section{Validation test of the maps}

Climatic factors are among the most important factors affecting plant growth. Therefore, climatic characteristics associated with the species being addressed are essential. In agricultural, forestry or horticultural studies, continuous surface climatic data are employed more effectively compared to pinpoint data. In recent years, developments in computer technologies have created new opportunities for researchers to conduct more detailed studies (Güler \& Kaya 2007). The thin plate spline interpolation method, a form of the regularized spline with tension method (RST) adopted in this study, was used by McKenney et al. (2001) to revise the
Canadian PHZ map. The RMSE value of the of annual extreme minimum temperatures map was less than $1{ }^{\circ} \mathrm{C}$, while the RMSE value for the average number of days with a temperature $\geq 30{ }^{\circ} \mathrm{C}$ was less than 2 days.

Based on the above evidence, in this study we decided to apply the RST method for pinpoint data interpolation and map production. However, the limited number and the geographic distribution of the meteorological data used in this study is a matter deserving to come under scrutiny. Most of the weather stations in Turkey are located next to urban areas, and only few are inside forested areas. For this reason, the distance between the stations considered in this study is approximately $70 \mathrm{~km}$. This uneven and sparse distribution may locally increase the error rates of the interpolated surface. As the effects of climatic changes are currently being felt with increasing strength, reliable climatic data are needed more than ever before. The majority of the developed world has already set up extensive meteorological networks, while the developing world is lagging behind due to budget cuts and different priorities (Güler \& Kaya 2007). Thus, the number of meteorological stations in the countryside in Turkey needs to be increased.

\section{Plant cold and heat hardiness zones in Turkey}

In the PHZ map produced for Europe by Heinze and Schreiber in 1984, PHZs 4 to 10 are generally encountered in central to southern Europe, while PHZ 3 is encountered in northern European countries, including Norway, Sweden and Finland. PHZs 1 and 2 are found beyond a latitude of $60^{\circ}$ in northern Russia. PHZs 4 to 10 can also be found in Turkey on the European PHZ map (Heinze \& Schreiber 1984). Overall, 7 of 13 PHZs can be found in Turkey. However, the European PHZ map is rather small in scale and depends upon old meteorological data. It has been reported that some shifts have occurred in PHZs due to changing climatic conditions (McKenney et al. 2001). In this study, at the same time a larger-scale map was produced, and a more detailed and up-to-date Turkish PHZ map was created using data from meteorological records from 1975 to 2008 .

The results of this study showed there were 7 PHZs in Turkey, whereas the majority of other European countries exhibited only 3 or 4 , which is believed to be the result of Turkey's geographic location and landforms. Turkey has the form of a peninsula, in which the terrestrial climate dominates the central part of the country, while steep mountainous terrain is located in its eastern region. These conditions cause numerous climatic types to take place over the countryside. For this reason, 8 of the $12 \mathrm{AHZs}$ can be found in Turkey. AHZ map, which represent a relatively new form of hardiness classification, have not been completed for Turkey and for the rest of Europe.

\section{Distribution of forest trees in plant cold hardiness zones}

Cold and heat hardiness zone maps are not useful in cases where the plants of interest can survive in zones which are not known; therefore, it is necessary to determine where plants survive through long-term observations.

Observations concerning cold hardiness have been recorded for many years. Many botanical books report plant characteristics in association with the USDA PHZs in which they survive. When a PHZ is specified, both the lower and upper zone boundaries are given in some cases, while in others only the lower boundaries are reported (Tab. 9). Additionally, there might be differences concerning the zone boundaries for particular species, which are thought to arise from observations performed outside their natural distribution area; however, such observations should be made within the species' natural range. Moreover, irrigation and fertilization treatments can bolster plant hardiness.

In this study, the PHZs in which several forest tree species occur in Turkey were identified and compared to the PHZs given in the literature. Concerning this analysis, the PHZs identified here for Quercus spp. were fairly similar to those reported in the literature. Species such as Abies spp., P. orientalis, $P$. nigra, $P$. sylvestris, C. libani, Juniperus spp., Alnus spp., C. sativa, F. orientalis, Carpinus spp. and L. orientalis were found in higher PHZs compared with previous studies (Tab. 9). As mentioned above, this might be due to the fact that the observations concerning these species were made outside of their natural distribution areas. In contrast, $P$. brutia, P. pinea and Eucalyptus spp. were found in lower PHZs as compared with evidence reported in the literature. This might be due to the extensive use of both species in plantations over the country. Moreover, since its complex geomorphology, there are numerous valleys and gorges showing specific microclimates in Turkey, and this affects climatic conditions over relatively short distances. However, depicting local conditions using the sparse weather station network currently in place is rather difficult.

\section{Distribution of forest trees in plant heat zones}

AHZ classification represents a relatively new methodology; for this reason, no AHZ has been determined for the majority of plants. Only 5 out of all of the investigated tree species are assigned to a specific AHZ in the literature. Of these species, Carpinus spp. was assigned to a similar AHZs in both 
this and previous studies. Picea orientalis, previously reported as associated to AHZs 81, was found within AHZs 5-4 in this investigation (Tab. 9). Moreover, the AHZs determined for Juniperus spp. were differen from zones previously determined for several Juniperus species. This may be due to the fact that data from forest inventories in Turkey are aggregated for several species of the genera Abies, Juniperus, Quercus, Carpinus and Alnus, and no species-level information were collected. Therefore, forest inventory must be conducted at the species level so that a more reliable information on the distribution of forest trees in Turkey could be obtained.

Hardiness zones have gained great importance due to a wide expansion of the horticulture sector in general, introducing new species and increasing the use of native species outside of their natural distribution areas (Mckenney et al. 2007). The most important advantage of PHZs is that the hardiness zones where most ornamental plants can be found have been determined based on observations performed over about a hundred years. This is the main reason that PHZ and AHZ classifications are preferable to other bioclimatic classifications, such as Köppen and De Martonne. Additionally, most bioclimatic classifications are based on climatic parameters such as temperature, precipitation and evapotranspiration, and represent climate characteristics in the natural distribution areas of plant species. Bioclimatic classifications based on water efficiency (such as the De Mortanne Aridity Index and Thornthwaite Precipitation Effectiveness Index) can be insufficient in the case of plant species growing outside of their natural distribution areas, or in areas where water deficiency is not a main limiting factor for plant growth. Furthermore, extreme temperatures have not been considered as a parameter in many bioclimatic classifications. Long-term observations demonstrated that extreme minimum and maximum temperatures were the most important limiting factor for plant growth in areas to be irrigated and fertilized, such as gardens. Extreme temperatures are used as a parameter in the Continentality and Thermicity Indexes developed by Rivas-Martinez (1996). Determination of the index values in which all species can be present is essential for common usage of these bioclimatic indices, which are quite new.

\section{Conclusion}

Plant hardiness zone maps may be disputed because of they are highly general, and the hardiness of a particular species can be dramatically affected by local conditions. Despite these drawbacks, the use of these maps is gradually becoming common. Along with the cold and heat hardiness maps produced in this study, the delineation of the zones in which some forest tree species can survive is becoming more critical in the selection of species to be planted. In addition to their use in forestry, plant hardiness zones are employed in the selection of species in other fields, especially in gardening.

\section{Acknowledgments}

The authors sincerely appreciate the cooperation provided by both the Turkish State Meteorological Service and the General Directorate of Forestry.

\section{References}

AHS (1997). Plant heat zone map. American Horticultural Society, Virginia, USA. [online] URL: http://www.ahs.org/pdfs/05_heat_map.pdf AHS (2005). Hardiness and heat zones and pronunciations. The American Gardener 84 (2): 61. [online] URL: http://www.ahs.org/publications/ the_american_gardener/pdf/0503/Heat_Zones_6 1.pdf

AHS (2006). Hardiness and heat zones and pronunciations. The American Gardener 85 (4): 62. [online] URL: http:/www.ahs.org/publications/ the_american_gardener/pdf/0607/Heat_Zones_6 2.pdf

AHS (2008). Hardiness and heat zones and pronunciations. The American Gardener 87 (1): 60 . [online] URL: http://www.ahs.org/publications/ the american gardener/pdf/08/01/Heat Zones 6 $0 . \overline{p d f}$

AHS (2010). Hardiness and heat zones and pronunciations. The American Gardener 89 (2): 60 [online] URL: http://www.ahs.org/publications/ the_american_gardener/pdf/10/03/Heat_Zones_6 $0 . p d f$

Atalay I (1977). Turkiye'de Çam Turlerinde Tohum Transfer Rejyonlamasi. Orman Agaclari ve Tohumlari Islah Enstitusu Mudurlugu Yayinlari, Yayin No. 1, Ankara, Turkey.

Atalay I (1984). Dogu Ladini (Picea orientalis L.) Tohum Transfer Rejiyonlamasi. Orman Agaclari ve Tohumlari Islah Arastirma Mudurlugu Yayinlari, Yayin No. 2, Ankara, Turkey.

Atalay I (1987). Sedir (Cedrus libani A. Rich) Ormanlarinin Yayilis Gösterdigi Alanlar ve Yakin Cevresinin Genel Ekolojik Özellikleri ile Sedir Tohum Transfer Rejiyonlamasi. Orman Genel Mudurlugu Yayinlari, Yayin No. 663/61, Ankara, Turkey.

Atalay I (1992). Kayin (Fagus orientalis Lipsky.) Ormanlarinin Ekolojisi ve Tohum Transferi Yonunden Bolgelere Ayrilmasi. Orman Agaclari ve Tohumlari Islah Arastirma Mudurlugu Yayinlari, Yayin No. 5, Ankara, Turkey.

Attorre F, Alfo M, De Sanctis M, Francesconi F, Bruno F (2007). Comparison of interpolation methods for mapping climatic and bioclimatic variables at regional scale. International Journal of Climatology 27 (13): 1825-1843. - doi: 10.1002/(ISSN)1097-0088

Bagnouls F, Gaussen H (1957). Les climates biologiques et leur classification. Annales de Geographie 355: 193-220. - doi: 10.3406/geo.1957. 18273
Cathey HM (1990). USDA plant hardiness zone map. Pub. no. 1475, USDA Misc., USDA, Washington, DC, USA. [map] [online] URL: http://www.usna.usda.gov/Hardzone/ushzmap.ht $\mathrm{ml}$

Cheers G (1999). Botanica: the illustrated A-Z of over 10,000 garden plants and how to cultivate them. Könemann, Hong Kong, pp. 1020.

Dawson I (1991). Plant hardiness zones for Australia. Australian Horticulture 90 (8): 37-39.

Del Tredici P (1990). The new USDA plant hardiness zone map. Arnoldia 50: 16-20. [online] URL: http://arnoldia.arboretum.harvard.edu/pdf/ articles/807.pdf

De Martonne E (1927). Regions of interior basin drainage. Geographical Review 17: 397-414. doi: $10.2307 / 208323$

Erinc S (1969). Klimatoloji ve Metotlari. Istanbul Universitesi, Cografya Enstitusu Yayinlari, Istanbul, Turkey.

Giddings LE, Soto-Esparza M (2005). Plant heat zones of Mexico. Revista Chapingo Serie horticultura 11: 365-369. [online] URL: http://redalyc.uaemex.mx/redalyc/pdf/609/60911 226.pdf

Grass Development Team (2008). Geographic resources analysis support system (GRASS) software. Open Source Geospatial Foundation Project. [online] URL: http://grass.osgeo.org

Güler M, Kaya T (2007). Alansal dagilim ozelligi gosteren iklim parametrelerinin cografi bilgi sistemleri ile belirlenmesi ve kullanim alanlari; genel bir bakis. Anadolu Journal of Agricultural Sciences 22: 322-328.

Heinze W, Schreiber D (1984). Eine neue Kartierung der Winterhärtezonen für Gehölze in Mitteleuropa. Mitteilungen der Deutschen Dendrologischen Gesellschaft 75: 11-56.

Isik F, Keskin S, Mc Keand SE (2000). Provenance variation and provenance-site interaction in Pinus brutia Ten.: consequences of defining breeding zones. Silvae Genetica 49: 213-223.

Johnson GR, Sorensen FC, St Clair JB, Cronn RC (2004). Pacific Northwest forest tree seed zones: a template for native plants. Native Plants: 131140. [online] URL: http://npj.uwpress.org/content $/ 5 / 2 / 131$.short

Köppen W (1936). Das geographische System der Klimate. In: "Handbuch der Klimatologie" (Koppen W, Geiger R eds). IC, Berlin, Germany.

Krüssmann G (1984). Manual of cultivated broadleaved trees and shrubs. Volume 1, Timber press, Beaverton, Oregon, USA.

Krüssmann G (1985a). Manual of cultivated broad-leaved trees and shrubs. Volume 2, B.T. Timber press, Portland, Oregon, USA.

Krüssmann G (1985b). Manual of cultivated conifers. Timber press, Portland, Oregon, USA.

Krüssmann G (1986). Manual of cultivated broadleaved trees and shrubs. Volume 3, B.T. Timber press, Portland, Oregon, USA.

Magarey RD, Borchert DM, Schlegel JW (2008). Global plant hardiness zones for phytosanitary risk analysis. Scientia Agricola 65: 54-59. - doi: 10.1590/S0103-90162008000700009

McKenney DW, Hutchinson MF, Kesteven JL, 
Venier LA (2001). Canada's plant hardiness zones revisited using modern climate interpolation techniques. Canadian Journal of Plant Sciences 81: 129-143. - doi: 10.4141/P00-030

Mckenney DW, Pedlar JH, Lawrence K, Campbell K, Hutchinson MF (2007). Beyond traditional hardiness zones: using climate envelopes to map plant range limits. Bioscience 57: 929-937. - doi: 10.1641/B571105

MEF (2007). Afforestation and erosion control rehabilitation action plan (2008-2012). Publications of Republic of Turkey, Ministry of Environment ant forestry, Ankara, Turkey. [online] URL: http://www.agm.gov.tr/AGM/Files/yayinlar/2008_2009_gerceklesme_rap_ing.pdf MEF (2010). Republic of Turkey National climate change strategy (2010-2020). Publications of Republic of Turkey, Ministry of Environment and Forestry, Ankara, Turkey. [online] URL: http://iklim.cob.gov.tr/iklim/Files/Stratejiler/National\%20Strategy.pdf

Mitas L, Mitasova H (1999). Spatial interpolation. In: "GIS: principles, techniques, management and applications" (Longley P, Goodchild MF, Maguire, DJ Rhind DW eds). Wiley, USA, pp. 481-492.

Mitasova H, Mitas L, Brown WM, Gerdes DP, Kosinovsky I, Baker T (1995). Modelling spatially and temporally distributed phenomena: new methods and tools for GRASS GIS. International Journal of Geographical Information Science 9 (4): 433-446. - doi: 10.1080/0269379950 8902048

Neteler M, Mitasova H (2002). Open Source GIS: a GRASS GIS approach (1 ${ }^{\text {st }}$ edn). Kluwer Academic Publishers, Boston, Dordrecht, London, pp. 464. [ISBN: 1-4020-7088-8]

National Arbor Day Foundation (2006). 2006 arborday.org hardiness zone map. [online] URL: http://www.freetrees.com/media/zones.cfm

Ouellet CE, Sherk L (1967a). Woody ornamental plant zonation I. Indices of winter hardiness. Canadian Journal of Plant Science 47: 231-238. doi: 10.4141/cjps67-044

Ouellet CE, Sherk L (1967b). Woody ornamental plant zonation II. Suitability indices of localities. Canadian Journal of Plant Science 47: 339-349. doi: 10.4141/cjps67-064

Ouellet CE, Sherk L (1967c). Woody ornamental plant zonation III. Suitability map for the probable winter survival of ornamental trees and shrubs. Canadian Journal of Plant Science 47: 351-357. - doi: 10.4141/cjps67-065

Rehder A (1927). Manual of cultivated trees and shrubs. Macmillan, New York, USA.

Rivas-Martinez S (1996). Clasificacion bioclimatica de la tierra. Folia Botanica Matritensis 16: 132.

Schmidtling RC (2001). Southern pine seed sources. Gen. Tech. Rep. SRS-XX, Southern Research Station, USDA Forest Service, Asheville, NC, USA, pp. 25.

Swedish Fuchsia Society (2012). USDA zones in Europe. [online] URL: https:/www2.dicom.se/ fuchsias/eurozoner.html

Thornthwaite CW (1948). An approach toward a rational classification of climate. Geographical Review 38: 55-94. - doi: 10.2307/210739
Tolunay D (1999). Ekoloji-Ekolojik FaktörlerEkolojik Sorunlar. "Cevre Seminerleri 1998. CEKUL Cevre Dizisi 2" .Globus Dunya Basimevi, Istanbul, Turkey, pp. 77-90.

TSMS (2011). 2010 Yili iklim verilerinin degerlendirmesi. Turkish State Meteorological Service, Ankara, Turkey. [online] URL: http://www.mgm.gov.tr/FILES/verideger/2010iklim-verileri.pdf

Türkes M, Tatli H (2009). Use of the standardized precipitation index (SPI) and a modified SPI for shaping the drought probabilities over Turkey. International Journal of Climatology 29: 22702282. - doi: $10.1002 /$ joc. 1862

USDA (2012). USDA plant hardiness zone map. Mapping by the Prism Climate Group, Oregon State University, Corvallis, OR, USA. [online] URL: http://planthardiness.ars.usda.gov/PHZMWeb/\#

Vogel KP, Schmer MR, Mitchell RB (2005). Plant adaptation regions: ecological and climatic classification of plant materials. Rangeland Ecology and Management 58: 315-319. - doi: 10.2111/ 1551-5028(2005)58[315:PAREAC]2.0.CO;2

Widrlechner MP (1997). Hardiness zones in China. North Central Regional Plant Introduction Station, Ames, I.A. [online] URL: http://www.ars.usda.gov/SP2UserFiles/Place/36 251200/Graphics/Climate_china.pdf

Wyman D (1938). Hedges, screens and windbreaks, McGraw-Hill, New York, USA, pp. 249.

Wyman D, Flint HL (1967). Plant hardiness-zone maps. Arnoldia 27: 53-56. 